\title{
THE EFFECT OF WORK ENVIRONMENT AND ORGANIZATIONAL CULTURE ON EMPLOYEES' PERFORMANCE THROUGH JOB SATISFACTION AS INTERVENING VARIABLE AT STATE ELECTRICITY COMPANY (PLN) OF SOUTH MAKASSAR AREA
}

\author{
${ }^{1}$ Hardiyono, ${ }^{2}$ Nurdjanah Hamid, ${ }^{3}$ Ria Mardiana $Y$ \\ ${ }^{1}$ Master Management, Faculty of Economics and Business Hasanuddin University \\ (email:dyonsrj@gmail.com) \\ ${ }^{2}$ Master Management, Faculty of Economics and Business Hasanuddin University \\ (email: nununghamid@gmail.com) \\ ${ }^{3}$ Master Management, Faculty of Economics and Business Hasanuddin University \\ (email: riamard67@gmail.com)
}

\begin{abstract}
The work environment is the important part of a company to improve the performance of employees. This study aimed to analyze the effect of the work environment and organizational culture on job satisfaction and employee performance at the State Electricity Company of South Makassar area. Thus, this study also analyzed the effect of job satisfaction on employees' performance at the State Electricity Company of South Makassar area. The data were collected through questionnaire. They were analyzed using path analysis with smart PLS 2.0. The sample consisted of 51 people at the State Electricity Company of South Makassar area. The results showed that the work environment and organizational culture have a positive and significant effect on the performance of the State Electricity Company of South Makassar area. It indicates that job satisfaction can mediate the effect of organizational culture on employees' performance at the State Electricity Company of South Makassar area which means the hypotheses in this research are accepted.
\end{abstract}

Keywords: Work environment, organizational culture, job satisfaction, performance 


\section{INTRODUCTION}

Performance (work performance) is an achievement and result for the implementation of certain tasks (Widodo, 2015). An employee has a good performance if that employee is able to do the same work or exceed the standards or criteria that have been set together in the organization. On the other hand, an employee hasn't a good performance if the work is less than the standards or criteria that have been set together. Successful and effective organizations are organizations with individuals who have good performance. In conclusion, if the employees who work in an organization have a good performance then effectiveness or success an organization will be achieved.

Improving work performance will be fulfilled if work environment supports daily work activities. Furthermore, the work environment in an organization is very important to note by management. A satisfactory work environment for employees increases improve performance, otherwise inadequate work environment decreases employee performance. Work environment, according to Nuraini (2013), is everything around the employees which affects in perform an assigned task, for example, the availability of the air conditioner (AC), adequate lighting etc. To design work environment, there are two things to note which are the physical environment and social environment in the workplace that aim equally to give effect in work comfortability. The work environment is good or applicable if people can perform activities optimally, healthy, safe and comfortable. Inadequate work environments may demand more labor and time and do not support the design of the efficient work systems (Sedarmayanti, 2011).

The importance of work environment in a company is the most important part because it will be able to improve employee performance. Dewi (2015), found that there is a significant influence between work environment and employee performance. In line with that, Sahlan et al (2015) show that the work environment, job satisfaction, and compensation simultaneously have a significant effect on employee performance.

Another considered factor in maintaining and improving employee performance is organizational culture. Organizational culture is thought to affect employee performance. Organizational culture is a very important role in supporting the creation of an organization to be efficient and effective. More specifically, organizational culture can play a role in creating an identity of the members of the organization, developing the participation of each member of the 
organization and presenting work performance guidelines for its members. The effectiveness of the organization can be enhanced by creating a strong culture, which can be used to achieve organizational goals. Riani (2011) stated that organizational culture as dominant values is spread in the organization which is used as work philosophy and guides the organization's policy in managing employees.

A strong organizational culture supports corporate goals, on the contrary, weak or negative things obstructs company goals. In a company with strong organizational culture, shared values are done strongly, embraced, and supported by most of its organizational members (company employees). Strong and positive culture is very influential on the behavior and effectiveness of company performance. Haryanti (2007), found that organizational culture has a positive and significant effect on employee performance. Thus, Susetyo et al (2014) also explained that organizational culture and work environment have a significant effect on employee performance.

In addition to the work environment and organizational culture, job satisfaction is also closely related to employee performance. A person who is satisfied with his work will have a high motivation, commitment to the company and strong work participation which keep improving his performance. If job satisfaction is not maintained, it may result in a lack of employee involvement and responsibility to the company. Handoko (2014), argued that job satisfaction is a pleasant or unpleasant emotional state by which employees view their work. Job satisfaction reflects one's feelings toward one's work. It shows an employee's positive attitude to the job and everything which are related to work environment.

Furthermore, this study aims to analyze the influence of work environment and organizational culture on job satisfaction at the State Electricity Company of South Makassar area. 


\section{RESEARCH METHODS}

\section{Research Design}

The research design is used as a guide in conducting the research process. Design research will be useful for all parties involved in the research process because the step in conducting research refers to the design research that has been made.

\section{Site and Time of Study}

In this study, researchers determine the object of research is the State Electricity Company (PLN) in South Makassar area, located on Hertasning street. Thus, this research required approximately three months starting from February to April of 2017.

\section{Population and Sample}

Population in this research is employees in State Electricity Company (PLN) of South Makassar area which amounts to 105 employees. Samples were taken from the group population. By taken sample of the population, it used Slovin formula with an error rate of $10 \%$, as Pardede (2014) explained as follows:

$$
\mathrm{N}=\frac{\mathrm{n}}{1+\mathrm{n}(\mathrm{e}) 2}
$$

Namely:

$\mathrm{n}$ : number of samples

$\mathrm{N}$ : number of population

e: error tolerance

A number of the sample in this study based on that formula is :

$$
\begin{aligned}
& \mathrm{n}=\frac{105}{1+105(0,10)^{2}} \\
& \mathrm{n}=\frac{105}{2,05} \\
& \mathrm{n}=51,21 \text { be rounded as } 51 \text { samples }
\end{aligned}
$$




\section{Collecting Data Method}

The data or information is from both inside and outside the company. The data is collected by the distribution of questionnaires to respondents which are employees of the State Electricity Company (PLN) South Makassar area through observation, interviews, documentation, and questionnaires.

\section{Data Analysis}

Data analysis in this research used path analysis and operated by software 2.0. PLS which can be used on any type of data scale (nominal, ordinal, interval, and ratio) as well as more flexible assumption terms. PLS is also used to measure the relationship of each indicator with its construct. In addition, PLS also tested bootstrapping against structural models which are an outer model and inner model.

\section{FINDINGS}

Table 1 shows the description of the respondents' responses to the working environment at the State Electricity Company of South Makassar Area where the score of work environment itself is 3.79. It is clear that the work environment at this present is categorized very well. It can be seen from respondent's perception that respondent's workplace is away from the noise. PLN of South Makassar area has a lot of customers who prefers comes to PLN Rayon rather than South Makassar area that makes this office is less noisy. Furthermore, more respondents agreed with their adequate workplace facilities showing how the work facilities in PLN of South Makassar area have supported the implementation of work.

Table 1

Description of Respondents Response on Working Environment at State Electricity Company Area South Makassar

\begin{tabular}{lllccccc}
\hline \multirow{2}{*}{ Code } & \multicolumn{1}{c}{ Statement } & \multicolumn{3}{c}{ Alternative Response } & \multicolumn{2}{c}{ Avarage } \\
\cline { 2 - 7 } X1.1 & $\begin{array}{l}\text { My workplace has less } \\
\text { noise }\end{array}$ & $3,9 \%$ & $9,8 \%$ & $37,3 \%$ & $45,10 \%$ & $3,9 \%$ & 3,35 \\
X1.2 & $\begin{array}{l}\text { My workplace has } \\
\text { some adequate } \\
\text { facilities }\end{array}$ & - & - & $37,3 \%$ & $39,2 \%$ & $23,5 \%$ & 3,85 \\
X1.3 & $\begin{array}{l}\text { Cleanliness in my work } \\
\text { environment makes me } \\
\text { working comfortable }\end{array}$ & - & $3,9 \%$ & $25,5 \%$ & $47,10 \%$ & $23,5 \%$ & 3,90 \\
X1.4 & $\begin{array}{l}\text { Lighting at work helps } \\
\text { me finishing my work }\end{array}$ & - & - & $39,2 \%$ & $41,2 \%$ & $19,5 \%$ & 3,80
\end{tabular}


$\begin{array}{llllll}\text { X1.5 } \begin{array}{lllll}\text { My working } \\ \text { environment is safe } \\ \text { which gives tranquility } \\ \text { for employee }\end{array} & 31,4 \% & 35,3 \% & 33,3 \% & 4,092 \\ \quad \text { Responden response avarage } & & & 3,79\end{array}$

Source: Primary Data, 2017

Table 2 shows the description of the respondents 'responses to the organizational culture in the State Electricity Company of South Makassar Area. It can be seen from the respondents' responses about the freedom of employees to give individual initiative in developing the organization which most of the respondents answered yes. Therefore, when PLN South Makassar area held Innovation Competition Program once a year as a moment where most of the employees were given freedom in giving individual initiative in progress of the organization. In line with that, most of the respondents answered agree rather than disagree when it comes to the opportunity given to take a risk while performing their work. This condition also supported by top management who always give chances to assist the employee such as PLN officer that suspends customer electricity who be in debt up to three months.

Table 2

Description of Responden Response on Cultural Organization at State Electricity Area South Makassar

\begin{tabular}{|c|c|c|c|c|c|c|c|}
\hline \multirow{2}{*}{ Code } & \multirow{2}{*}{ Statement } & \multicolumn{5}{|c|}{ Alternative Response } & \multirow[t]{2}{*}{ Avarage } \\
\hline & & STS & TS & CS & $\mathrm{S}$ & SS & \\
\hline $\mathrm{X} 2.1$ & $\begin{array}{l}\text { Company gives } \\
\text { freedom for each } \\
\text { employee to give } \\
\text { individual initiative }\end{array}$ & - & $3,9 \%$ & $23,5 \%$ & $68,6 \%$ & $3,9 \%$ & 3,73 \\
\hline $\mathrm{X} 2.2$ & $\begin{array}{l}\text { Company gives } \\
\text { opportunity for } \\
\text { employees to take risks } \\
\text { in carrying out their } \\
\text { work }\end{array}$ & - & $3,9 \%$ & $15,7 \%$ & $56,9 \%$ & $23,5 \%$ & 4 \\
\hline $\mathrm{X} 2.3$ & $\begin{array}{l}\text { Company always give } \\
\text { guidance on every job }\end{array}$ & - & $5,9 \%$ & $15,7 \%$ & $18,8 \%$ & $19,6 \%$ & 3.92 \\
\hline $\mathrm{X} 2.4$ & $\begin{array}{l}\text { Employees are able to } \\
\text { adjust with company } \\
\text { regulation }\end{array}$ & - & $7,8 \%$ & $17,6 \%$ & $60,8 \%$ & $13,7 \%$ & 3,80 \\
\hline \multirow[t]{2}{*}{$\mathrm{X} 2.5$} & Company provides & - & $7,8 \%$ & $19,6 \%$ & $47,10 \%$ & $25,5 \%$ & 3,90 \\
\hline & \multicolumn{6}{|c|}{ Average score of responses } & 3,87 \\
\hline
\end{tabular}


Table 3 shows the response of respondents about employee job satisfaction in PLN South Makassar area. It is clear that employees were satisfied with work environment related to psychiatric employees where dominant respondents agreed. This satisfaction was also supported by the implementation of Occupational Safety and Health Management System (SMK3) in PLN Office Area South Makassar. Hence, more respondents said agree related to physical condition of the work environment which mean that employees are satisfied with the physical condition of the work environment. The physical condition of PLN Area South Makassar is very well supported by the complete facilities and infrastructure to assist the employee work.

Table 3

Description of Respondent Responses on Job Satisfaction at State Electricity Area South Makassar

\begin{tabular}{|c|c|c|c|c|c|c|c|}
\hline \multirow{2}{*}{ Code } & \multirow{2}{*}{ Statement } & \multicolumn{5}{|c|}{ Alternative Response } & \multirow[t]{2}{*}{ Avarage } \\
\hline & & STS & $\mathrm{TS}$ & $\mathrm{CS}$ & $\mathrm{S}$ & SS & \\
\hline Y1.1 & $\begin{array}{l}\text { Employees are } \\
\text { satisfied with work } \\
\text { situations related to } \\
\text { the psycological } \\
\text { employees }\end{array}$ & - & - & $19,6 \%$ & $66,76 \%$ & $13,76 \%$ & 3,94 \\
\hline Y1.2 & $\begin{array}{l}\text { Employees are } \\
\text { satisfied with } \\
\text { physical condition of } \\
\text { work environment }\end{array}$ & - & - & $21,6 \%$ & $60,8 \%$ & $17,6 \%$ & 3,96 \\
\hline Y1.3 & $\begin{array}{l}\text { Employees meet } \\
\text { their need on } \\
\text { financial in order to } \\
\text { fullfil their daily } \\
\text { needs }\end{array}$ & - & $2 \%$ & $17,6 \%$ & $56,9 \%$ & $23,5 \%$ & 4,02 \\
\hline Y1.4 & $\begin{array}{l}\text { Conducting social } \\
\text { interaction both } \\
\text { employees with } \\
\text { employers and } \\
\text { between employees } \\
\text { in different types of } \\
\text { work }\end{array}$ & - & - & $9,8 \%$ & $56,9 \%$ & $33,36 \%$ & 4,24 \\
\hline \multicolumn{7}{|c|}{ Average score of Responses } & 3,04 \\
\hline
\end{tabular}

Source: Primary Data, 2017 


\section{DISCUSSION}

The results of data analysis have been done empirically. It shows the work environment of PT. PLN Area South Makassar has gone well which gave positive feedback on job satisfaction. It can be seen from the comfortable work environment even though this office has a lot of customer coming. The availability of work facilities has supported the working process which affected job satisfaction.

It is seen by the observation that the work environment has been able to increase job satisfaction significantly within PLN Area South Makassar. The cleanliness area of PLN Area Makassar South has been supported by the implementation of SMK3. According to research by Sahlan et al (2015), which found that the work environment has a significant effect on job satisfaction and then supported by the research of Susetyo et al (2014), which found that the work environment has a significant effect on the work performed.

Furthermore, the organizational culture has a positive effect on job satisfaction based on path analysis score. The result also shows that organizational culture can improve employee job satisfaction. On the other hand, partial tests score shows that organizational culture has a significant effect on employee job satisfaction. The findings of this study in line with research conducted by Fauzi et al (2016), where the results found that there is a positive and significant influence between organizational culture on job satisfaction.

Based on the analysis results of work environment with employee performance, there was a positive effect on work environment to employee performance. The better working environment at PLN Area South Makassar will be able to improve employee performance. It can be seen from the working environment conditions at PLN Area South Makassar which has been providing cleanliness and amenity. It also supported by the availability of facilities and infrastructure that always maintained with the running program of SMK3. Hence, a good air and window position for lighting already supported work environment.

According to the results of partial tests show that the work environment affected significantly employee performance. The findings of this study are supported by previous research by Dewi (2015), who found that the work environment had a significant effect on employee performance. Similarly, other research that supports the results of this study is from Susetyo et al (2014), found that the work environment has a significant effect on employee performance. Therefore, the findings of this study also supported several previous studies. 


\section{CONCLUSIONS AND RECOMMENDATION}

\section{Conclusion}

Based on the results of the analysis and discussion, it will be presented some conclusions as follows:

1. The results of this research analysis indicate that the work environment has a positive and significant impact on satisfaction in the State Electricity Company Area South Makassar. It can be seen from the work environment that provided security and tranquility for employees which also gave satisfaction to employees.

2. The results of this research analysis indicate that the work environment has a positive and significant effect on employee performance in the State Electric Company Area South Makassar. It was supported by safety in work environment which gave positive feedback on concentration and performance.

3. The results of this research analysis indicate that organizational culture has a positive and significant impact on job satisfaction at the State Electricity Company Area South Makassar.

Employees feel satisfied on doing their job because the company supported them if they took a risk while performing their work.

4. The results of this research analysis indicate that organizational culture has a positive and significant impact on employee performance in the State Electric Company Area South Makassar. It can be seen from the guidelines on each job in order to optimize employee performance.

5. The results of this research analysis indicate that job satisfaction has a positive and significant effect on employee performance in State Electric Company Area South Makassar. The existence of a good social interaction between fellow employees, with employers and employees of different types of jobs provide a satisfaction that impacts on employee's performance.

6. The results of this research analysis indicate that job satisfaction can mediate the influence of work environment on employee performance at State Electric Company Area South Makassar. It was supported by safeties and tidiness of work environment which improved work performance.

7. The results of the analysis of this study indicate that job satisfaction can mediate the influence of organizational culture on employee performance in the State Electric Company Area South Makassar. It can be seen from giving an opportunity to innovate and courage to take the risk which optimized their performance. 


\section{Recommendations}

The recommendations are as follows:

1. The work environment gives a big influence on job satisfaction so the company must maintain the working environment which currently has generally support employee's performance at the Office of Perusahaan Listrik Negara Area South Makassar. But there are things that still need to be considered namely security and comfort. It included adding new facilities such as a new air condition.

2. The loudness factor also becomes an important thing for the influence of work environment on employee performance. Even though this office has less noise than other PLN office but it would be better to put some silencer equipment.

3. The influence of organizational culture in this study gives a positive impact but still low influence than the influence of other variables on job satisfaction. It can be caused by frequent teamwork in work, or guidance before carrying out the task so that employees feel satisfied and noticed by the company.

4. The influence of culture on employee performance that gives employees the freedom to innovate in the work also become an important thing to note. They need more freedom to be an able improving initiative in organizational development.

5. Things to consider on improving employee job satisfaction that affects the employee's performance are to enhance work environment in a psychiatric condition such as providing a comfortable workplace and supportive work facilities. In line with that, the management should provide time to share employee knowledge and held a job training at least every two months or addition of higher education to the employee. 


\section{References}

Dewi I. S. (2015). Pengaruh Kepuasan Dan Lingkungan Kerja Terhadap Kinerja Karyawan Dengan Perilaku Kewargaan Organisasional Sebagai Variabel Intervening (Studi pada Karyawan PT Indonesian Knitting Factory Semarang) (Doctoral dissertation, Universitas Negeri Semarang).

Fauzi M., Warso M.M., \& Haryono A.T. (2016). Pengaruh Budaya Organisasi dan Kepuasan Kerja Terhadap Kinerja Karyawan dengan Komitmen Organisasi Sebagai Variabel Intervening (Studi Pada Karyawan PT. Toys Games Indonesia Semarang). Journal of Management Vol. 02 No. 02, Maret 2016.

Handoko H.T. (2014). Manajemen Personalia dan Sumber Daya Manusia. Edisi Kedua. Penerbit : BPFE, Yogyakarta

Hariyanti D. 2007). Analisis Pengaruh Budaya Organisasi, Kepuasan Kerja, dan Gaya Kepemimpinan Terhadap Kinerja Karyawan Dengan Komitmen Organisasional Sebagai Variabel Interverning (Studi PT. PLN (Persero) APJ Semarang) Jurnal Tesis Universitas Diponegoro Semarang

Nuraini T. (2013). Manajemen Sumber Daya Manusia, Penerbit : Yayasan Aini Syam : Pekanbaru.

Pardede R. (2014). Analisis Jalur Path Analysis Teori dan Aplikasi Dalam Riset Bisnis, edisi pertama, cetakan pertama, Penerbit : Rineka Cipta, Jakarta

Riani L.A. 2011. Budaya Organisasi. Edisi Pertama, Penerbit : Graha Ilmu, Yogyakarta

Sahlan I.N., Peggy A.M., \& Irvan T. (2015). Pengaruh Lingkungan Kerja, Kepuasan Kerja dan Kompensasi Terhadap Kinerja Karyawan Pada PT. Bank Sulut Cabang Airmadidi. Jurnal Vol. 3 No. 1 (2015)

Sedarmayanti. (2011). Manajemen Sumber Daya Manusia, Reformasi Birokrasi dan Manajemen Pegawai Negeri Sipil (cetakan kelima). Penebit : Refika Aditama, Bandung

Susetyo, Widyanto E., Kusmaningtyas A., \& Tjahjono H. (2014). Pengaruh Budaya Organisais dan Lingkungan Kerja Terhadap Kepuasan Kerja dan Kinerja Karyawan Pada PT. Bank Muamalat Indonesia Divisi Konsumer Area Cabang Surabaya. Jurnal Ekonomi dan Manajemen, April 2014, Vol. 1 No. 1

Widodo E.S. (2015). Manajemen Pengembangan Sumber Daya Manusia. Cetakan Pertama. Penerbit : Pustaka Pelajar, Yogyakarta 